\title{
Originals
}

\section{Sustained Insulin-Induced Remissions of Juvenile Diabetes by Means of an External Artificial Pancreas}

\author{
J. Mirouze, J. L. Selam, T. C. Pham, E. Mendoza, and A. Orsetti \\ Clinique des Maladies Métaboliques et Endocriniennes, Hôpital Saint-Eloi, Montpellier, France
}

\begin{abstract}
Summary. Remission of diabetes was attempted in 12 recent acute onset ketosis-prone juvenile diabetes after short term ( $5 \pm 1$ days) but excellent blood glucose control by the external artificial beta-cell. The comparison group comprised patients undergoing traditional treatment $(\mathrm{n}=28)$. Nine $(75 \%)$ persistent (over 3-14 months of duration) although partial (oral drugs required) remissions were obtained in the former group as compared to $3(11 \%)$ in the latter group $(\mathrm{p}<0.05)$. Cases which showed remissions after insulin infusion had a plasma insulin response to IV glucagon still present before insulin infusion, and a daily urinary $\mathrm{C}$-peptide excretion significantly enhanced after $(\mathrm{p}<0.01)$. Urinary C-peptide/blood glucose remained improved during the remission period. Thus, early effective treatment by means of the artificial pancreas may break the vicious circle hyperglycaemia-insulin depletion-hyperglycaemia and lead to frequent and sustained remissions of juvenile diabetes.
\end{abstract}

Key words: Continuous blood glucose monitoring, artificial beta cell, juvenile diabetes, remission of diabetes, C-peptide.

Juvenile diabetics are generally insulin dependent. With acute onset, the presence of ketosis classically indicates severe insulin deficiency. Remissions have been noted in the early stage of the disease and seem to be related to early and effective blood glucose control $[1,2,3,4,5]$. However, discontinuation of insulin therapy is rarely possible and the remissions are partial and of short duration $[3,4,6]$.

Venous automated continuous insulin infusion assessed by the external artificial beta cell is now the best method of constant blood glucose control $[7,8]$. For this reason, the induction of a remission period was attempted using this type of treatment in cases of recent acute onset juvenile diabetics with severe insulin deficiency. A conventionally treated group was used for comparison.

\section{Patients and Methods}

\section{Patients}

Forty non obese acute onset juvenile diabetics were studied (age $17.8+1.2$ years, duration of diabetes $41.6 \pm 6.9$ days). Strict insulin dependency was confirmed by sustained high blood glucose (mean fasting values measured at 7 a. m., 12,6 p. m., 0,4 a. m. : $332 \pm 16 \mathrm{mg} / 100 \mathrm{ml}$, mean post absorptive values measured $90 \mathrm{~min}$ after the main meals i. e. at 9 a. m., 2 p. m., 8 p. m. : $389 \pm 16 \mathrm{mg} / 100 \mathrm{ml})$ and ketonuria under strict dietary conditions ( $213 \pm 6 \mathrm{~g}$ carbohydrate $/ 24 \mathrm{~h}$ ) and oral hypoglycaemic agents (glibenclamide, $15 \mathrm{mg} / 24 \mathrm{~h}$, metformin, $1700 \mathrm{mg} / 24 \mathrm{~h}$ ) in the absence of any additional drugs and diabetogenic factors. Patients were allocated to one of two treatment groups (Table 1):

Patients of group A $(n=12)$ received a $24 \mathrm{~h}$ continuous Actrapid insulin (Novo, 40 units per ml) infusion by means of an external artificial beta-cell [8]. Continuous blood glucose measurement was achieved by a modified glucose oxidase method (G. O.D.-P.A.P. Boehringer). Effective blood glucose control was obtained, the values varying from 60 $\mathrm{mg} / 100 \mathrm{ml}$ in the fasting state to $150 \mathrm{mg} / 100 \mathrm{ml}$ in the post-absorptive state. Then oral treatment was given again for 2-3 days and changed to SC insulin therapy $\left(N^{\circ} 3,4\right)$ if net relapse of diabetes occurred, maintained $\left(\mathrm{N}^{\circ} 1,2\right)$ if there was net improvement of 

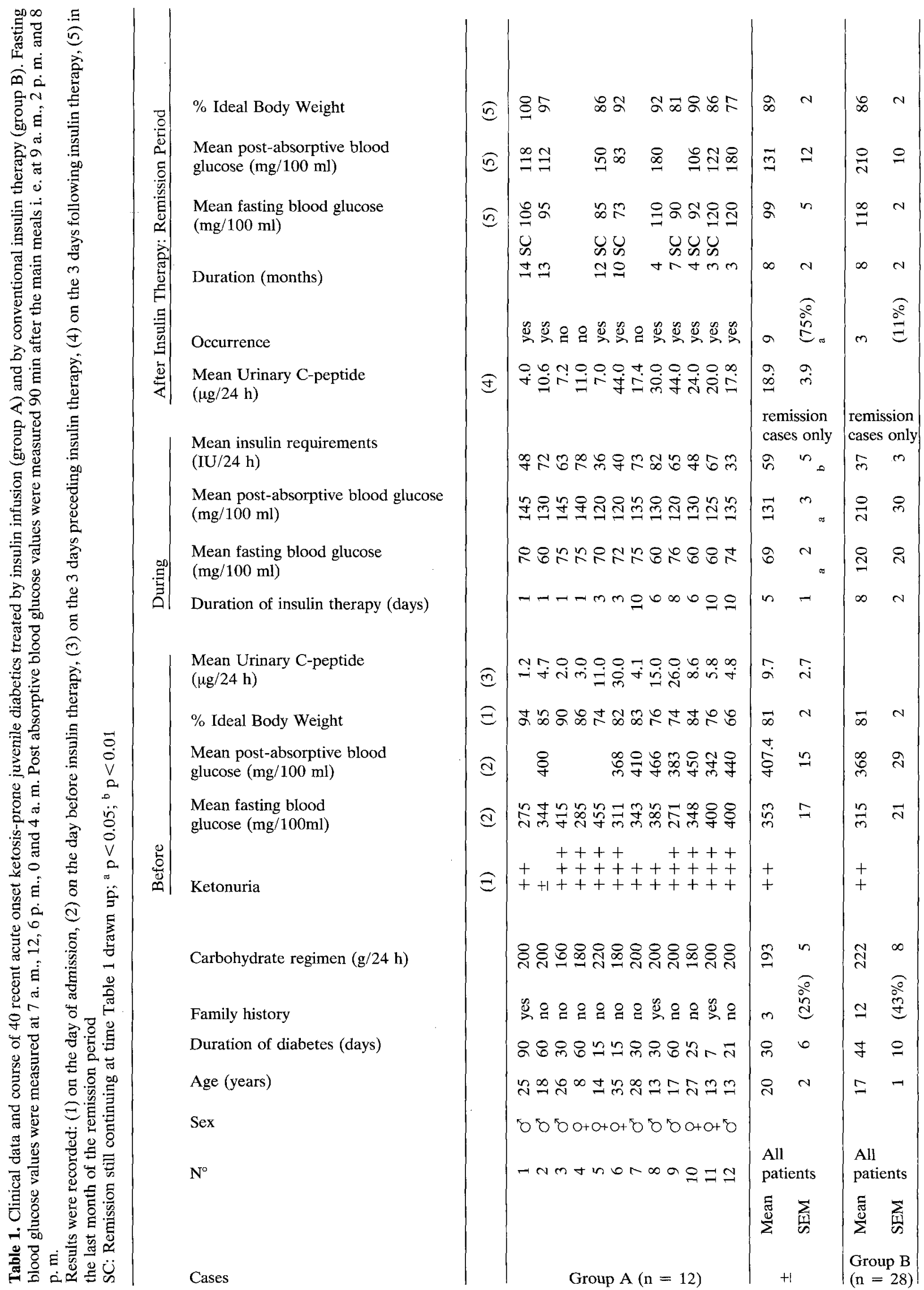
diabetes, - or changed again, if there was only slight improvement, to other $12-24 \mathrm{~h}$ periods of insulin infusion as long as gradual improvement of diabetes was noted after each period.

Patients of group B were conventionally treated by three daily Actrapid and Semi-lente (Novo 40 units per $\mathrm{ml}$ ) SC insulin injections during $8 \pm 2$ continuous days. Mean daily insulin administered was significantly lower than in patients of group A $(\mathrm{p}<0.01)$. Discontinuous blood glucose measurements (glucose oxidase method) showed poorer diabetic control.

\section{Methods}

Clinical remission was defined, after the initial venous (group A) or subcutaneous (group B) insulin therapy, when good (aglycosuria, fasting blood glucose $<120 \mathrm{mg} / 100 \mathrm{ml}$, post absorptive blood glucose $<200 \mathrm{mg} / 100 \mathrm{ml}$ ) and long duration ( $\geqslant 3$ months) diabetes control was obtained by both the same diet and the same oral hypoglycaemic agents which were previously ineffective.

Beta cell function was evaluated in patients of group A: $1 \mathrm{mg}$ glucagon (Novo) was injected intravenously on the first day of insulin therapy just before insulin infusion and blood samples withdrawn every 5 minutes for 30 minutes. Immunoreactive plasma insulin was assayed using the Hales and Randle method [9].

Daily urinary immunoreactive C-peptide excretion (Daiichi Radio Isotopes Labs, Ltd, Tokyo) was measured according to Horwitz et al. [10] (normal values: $36 \pm 4 \mu \mathrm{g} / 24 \mathrm{~h}$ ) every day during the whole period of intensive treatment and every month during the remission period. Cross reaction with human proinsulin was negligible.

Results are given as means \pm standard error of the mean (SEM). Significance is given inside group A by paired t-test. Significant differences between the two groups have been sought by Student's t-test and the Fisher test after verification of parametric distribution.

\section{Results}

Nine patients from group A $(75 \%)$ showed steady remissions of diabetes - as defined above - a few days after insulin infusion (Table 1) (mean duration of remissions $8 \pm 2$ months, range 3-14 months). Six remissions are still continuing while 3 patients $\left(\mathrm{N}^{\circ} 2\right.$, $8,12)$ relapsed after 13,4 and 3 months remission. They received a second insulin infusion treatment

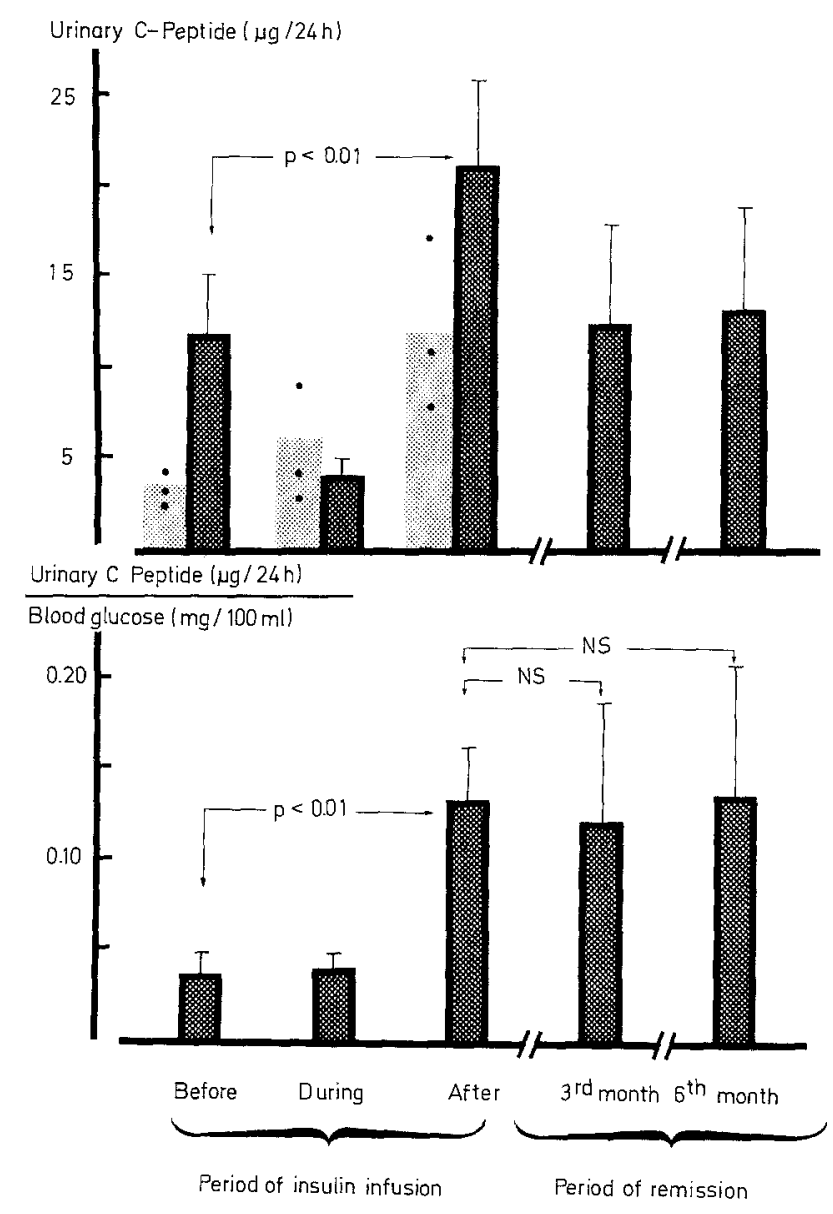

Fig. 1. Mean daily urinary C-peptide excretion (upper part of the figure) and urinary C-peptide/blood glucose ratio (lower part of the figure) in patients of group A without remissions (grey, mean + range) and with remissions (black, mean \pm SEM).

Mean urinary $\mathrm{C}$-peptide was calculated on the 3 days preceding and following insulin therapy $(\mathrm{n}=12)$, then on one $24 \mathrm{~h}$ urine sample taken during the 3rd month $(\mathrm{n}=6)$ and the 6th month $(n=4)$ of the remission period.

Mean blood glucose was evaluated on the days of urine C-peptide determinations from 8 diurnal samples taken at 7 a. m., 9 a. m., 12 a. m., 2 p. m., 6 p. m., 8 p. m. 0 and 4 a.m.

NS: nonsignificant

which was effective only in one patient $\left(\mathrm{N}^{\circ} 2\right)$, but this result is too recent to draw any firm conclusions.

Only 3 patients from group B $(11 \%, \mathrm{p}<0.05)$ showed remissions of diabetes after subcutaneous insulin therapy (Table 1). One patient relapsed after 6 months, the two others after 10 months and all received subcutaneous insulin therapy.

The results of the daily urinary C-peptide excretion measured in patients of group $\mathrm{A}$ are shown in Figure 1. Pre-insulin therapy levels $(11.9 \pm 3.3 \mu \mathrm{g}$ / $24 \mathrm{~h}$ ) decreased during and significantly increased $(\mathrm{p}<0.01)$ after insulin infusion $(21.3 \pm 4.8 \mu \mathrm{g} / 24 \mathrm{~h})$ in patients with subsequent-remission.

C-peptide gradually decreased to pre-treatment 


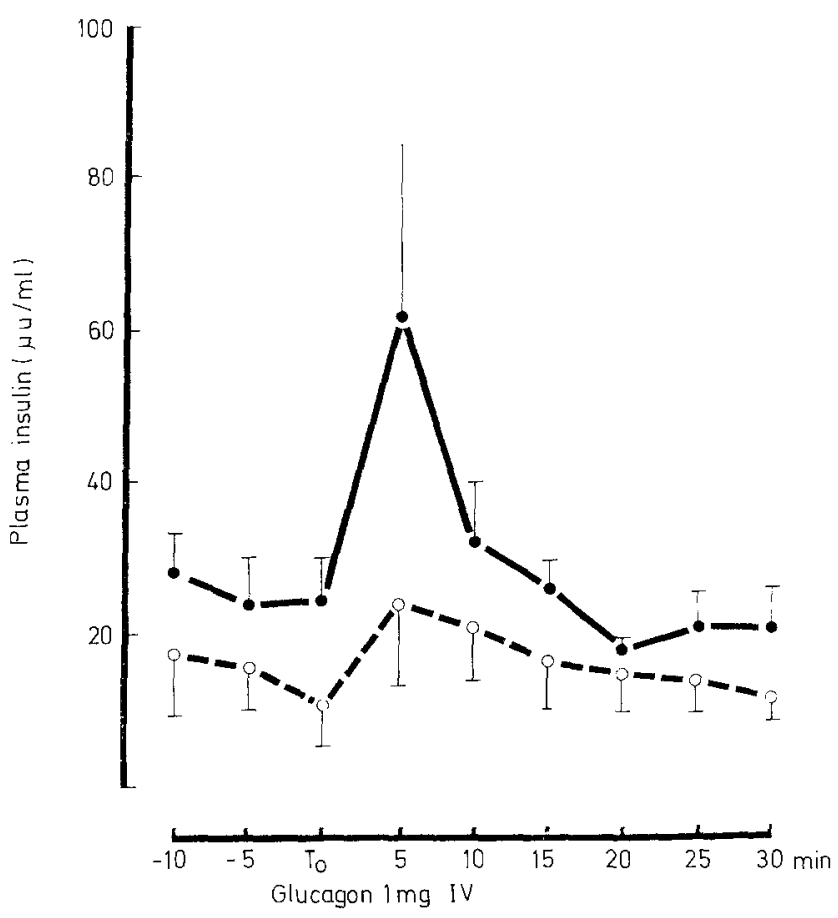

Fig. 2. Glucagon-induced insulin secretion tests performed just before insulin infusion in 3 patients with absent $\left(\mathrm{N}^{\circ} 7\right)$ or short duration ( $\mathrm{N}^{\circ} 8$ and 12$)$ remissions (dotted line) and 3 patients $\left(\mathrm{N}^{\circ}\right.$ 5,6 and 10 ) with persistent remissions (solid line)

levels during the remission period, but the urinary Cpeptide/blood glucose ratio did not change significantly (Fig. 1). Patients without remission excreted lower amounts of C-peptide both before (mean 3.0 $\mu \mathrm{g} / 24 \mathrm{~h}$, range $2.0 \pm 4.1 \mu \mathrm{g} / 24 \mathrm{~h}$ ) and after (mean $11.9 \mu \mathrm{g} / 24 \mathrm{~h}$, range $7.2-17.4 \mu \mathrm{g} / 24 \mathrm{~h}$ ) insulin infusion.

The results of IV glucagon tests performed just before the insulin infusion in 6 patients from group $A$ are shown in Figure 2. Plasma insulin responsiveness to IV glucagon was higher in patients with sustained remissions $\left(\mathrm{N}^{\circ} 5,6\right.$ and 10$)$ than in patients with absent $\left(\mathrm{N}^{\circ} 7\right)$ or short duration $\left(\mathrm{N}^{\circ} 8\right.$ and 12$)$ remissions, although the numbers are too small to draw any firm conclusions.

\section{Discussion}

Different degrees of metabolic improvement following the manifestation of diabetes have been called "remission", a somewhat confusing term $[3,4,6,11$, 12]. In the present work remission was considered to be present when, under identical clinical and dietary conditions, in non obese, recent onset, ketosis-prone juvenile patients early after the initiation of insulin therapy, diabetes might be controlled without exogenous insulin administration for more than three months.

According to this definition, spontaneous remissions were rare $(11 \%)$. By contrast, more frequent $(75 \%, \mathrm{p}<0.05)$ persistent remissions (duration $8 \pm$ 2 months) were demonstrated after transient but excellent blood glucose control via the artificial betacell. Residual insulin secretion was not assessed in Group B patients and it is possible that the two groups could have contained significantly different numbers of patients with appreciable residual secretion of insulin. However, all patients in remission required oral drugs and three of them relapsed after a few months (range 3-13 months) indicating that insulin infusion induced only temporary and partial remissions.

The underlying mechanism of these clinical remissions is poorly understood. However, a residual insulin secretion is present in most insulin dependent diabetics $[13,14,15]$, particularly in patients who show remissions [16-20]. This is confirmed in the present work by the daily urinary C-peptide excretion and the glucagon-induced insulin response. On the contrary, variations in insulin secretion induced by exogenous insulin have been poorly studied, with conflicting results $[12,21,22,23]$.

In the present work, urinary C-peptide was lowered by insulin infusion and significantly $(p<0.01)$ enhanced immediately after (Fig. 1). When considered in relation to ambient glood glucose, urinary C-peptide excretion remained improved during the remission period.

The remission state might be interpreted as a preservation of the residual beta-cell function by early adequate insulin therapy [24], allowing an improvement of the secretion when discontinued. Because Cpeptide secretion is stopped only if blood glucose is reduced below $80 \mathrm{mg} / 100 \mathrm{ml}$ [25], beta-cells can be rested only by a really effective treatment such as the automated insulin infusion via the artificial pancreas. By contrast, as in patients of group B, conventionally "well treated" diabetics are generally undertreated (Table 1) and the resulting mild hyperglycaemia makes amelioration of diabetes rare and weak (Table 1). The "rebound effect" of insulin secretion after insulin infusion may reflect a somewhat beneficial action of transient hyperglycaemia on beta-cell secretion or replication provided high blood glucose levels are not prolonged over 3 days so as to lead to exhaustion of the beta-cells [26]. For this reason, intervals between insulin infusion periods in our protocol did not exceed 2-3 days. We are now studying the effect of continuous prolonged insulin infusions on the occurrence of remissions.

Our initial results thus suggest that acute onset 
juvenile diabetes, at least in its early stage, could be interpreted as a partially self-supporting disease: early normalization of blood glucose by the artificial beta-cell may break the vicious circle hyperglycaemia-insulin depletion-hyperglycaemia and lead to much more frequent and sustained remissions of diabetes than usually reported.

\section{References}

1. Jackson, R.L., Boyd, J.D., Smith, R. E.: Stabilization of diabetic children. Am. J. Dis. Child. 59, 332-341 (1940)

2. Brush, J. M.: Initial stabilization of diabetic children. Am. J. Dis. Child. 67, 429-444 (1944)

3. Jackson, R.L., Onofrio, J., Waiches, H., Guthrie, R. A.: The "honeymoon period": partial remission of juvenile diabetes mellitus. Diabetes 20 (suppl. 1), 361 (1971)

4. Pirart, J., Lauvaux, J.P.: Remission in diabetes. In: E. F. Pfeiffer (Ed.): Handbook of diabetes mellitus, 2, 443-502. München: Lehmans Verlag 1972

5. Ludvigsson, J., Heding, L. G., Larsson, Y., Leander, E.: Cpeptide in juvenile diabetics beyond the post initial period. Acta Paediatr. Scand. 66, 177-184 (1977)

6. Harwood, R.: Severe diabetes with remission. N. Engl. J. Med. 257, 257-261 (1957)

7. Mirouze, J., Selam, J. L., Pham, T. C.: Infusion insulinique par débit asservi à l'enregistrement glycémique continu. Journ. Annu. Diabetol. Hotel Dieu, 302-312. Paris: Flammarion 1976

8. Mirouze, J., Selam, J.L., Pham, T.C.: Evaluation of exogenous insulin homeostasis by the artificial pancreas in insulin dependent diabetics. Diabetologia 13, 273-278 (1977)

9. Hales, C. N., Randle, P. J.: Immuno-assay of insulin with antibody precipitate. Biochem. J. 88, 137 (1963)

10. Horwitz, D. L., Rubenstein, A. H., Katz, A. I.: Quantitation of human pancreatic beta cell function by immunoassay of Cpeptide in urine. Diabetes 26, 30-35 (1977)

11. Weber, B.: Glucose stimulated insulin secretion during "remission" of juvenile diabetes. Diabetologia 8, 189-195 (1972)

12. Block, M.B., Rosenfield, R.L., Mako, M.E., Steiner, D. F., Rubenstein, A.H.: Sequential changes in beta-cell function in insulin treated diabetic patients assessed by C-peptide immunoreactivity. J. Clin. Endocrinol. Metab. 35, 402-406 (1972)

13. Ludvigsson, J., Heding, L. G.: C-peptide in children with juvenile diabetes. Diabetologia 12, 627-630 (1976)
14. Binder, C., Faber, O. K., Heding, L. G.: Plasma C-peptide response to glucagon as a measure of beta-cell function on insulin dependent diabetes mellitus. In: J.S. Bajaj (Ed.): Abstracts of the 9th Congress of the International Diabetes Federation, New Delhi, 22, Amsterdam: Excerpta Med. 1976

15. Chiumello, G., Del Guarcio, M.J., Bidone, G.: Effects of glucagon and tolbutamide on plasma insulin levels in children with ketoacidosis. Diabetes 17, 133-135 (1968)

16. Genuth, S.M.: Clinical remission in diabetes mellitus. Diabetes 19, 116-121 (1970)

17. Enk, B., Deckert, T.: Insulin secretion in insulin requiring diabetics before and during insulin treatment. Diabetologia 11, $340(1975)$

18. Hernandes, A., Zorilla, E., Gershberg, H.: Serum insulin in remission of juvenile diabetes. Lancet $1968 \mathrm{II}, 223$

19. Johansen, K., Ørskov, H.: Plasma insulin during remission in juvenile diabetes mellitus. Br. Med. J. 1969 I, 676-678

20. Kosaka, K., Hagura, R., Saito, R., Rsukamoto, F., Kusuya, T.: Changes in plasma insulin and glucose tolerance in stable diabetes in a young woman. Diabetes 18, 487-492 (1969)

21. Block, M. B., Mako, M. E., Steiner, D. F., Rubenstein, A. H.: Diabetic keto-acidosis: Evidence for C-peptide and proinsulin secretion following recovery. J. Clin. Endocrinol. Metab. 35, 402-406 (1972)

22. Turner, R. C., McCarthy, S. T., Holman, R. R., Harris, E.: Beta-cell function improved by supplementing basal insulin secretion in mild diabetes. Br. Med. J. 1976 I, 1252-1254

23. Holman, R. R., Turner, R. C.: Diabetes: the quest for basal normoglycaemia. Lancet 1977 I, 469-474

24. Campbell, J., Haist, R. E., Ham, A. W., Best, C. H.: The insulin content of the pancreas as influenced by anterior pituitary extract and insulin. Am. J. Physiol. 129, 328 (1940)

25. Zilker, Th., Ermler, R., Bottermann, P.: C-peptide secretion according to glucose and insulin levels. In: J.S. Bajaj (Ed.): Abstracts of the 9th Congress of the International Diabetes Federation, New Delhi, 31-32. Amsterdam: Excerpta Med. 1976

26. Hellerstrom, C., Andersonn, A., Gunnarsson, R.: Regeneration of islet cells. International Symposium on the Immunological aspects of diabetes mellitus. Acta Endocrinol. (Kbh.) [Suppl. ] 205, 145-158 (1975)

Received: August 1, 1977,

and in revised form: October 26, 1977

Prof. J. Mirouze

Clinique des Maladies Métaboliques

et Endocriniennes

Hôpital Saint-Eloi

F-34059 Montpellier Cedex

France 